\title{
PENGARUH DISIPLIN KERJA MOTIVASI KERJA, UPAH KERJA DAN LINGKUNGAN KERJA TERHADAP PRODUKTIVITAS KERJA DI UNIT USAHA JASA INDUSTRI DAN ANEKA PANGAN POLITEKNIK NEGERI JEMBER
}

\author{
Oleh: \\ ENDANG WIDYAWATI NINGRUM *) \\ WENNY DHAMAYANTHI DAN RATIH PUSPITORINI Y.A **)
}

Suatu organisasi yang kompetitif memerlukan adanya dukungan dari seluruh sumber daya yang ada untuk meningkatkan kinerja dengan baik. Kajian empiris menyatakan bahwa faktor - faktor yang dapat mempengaruhi terhadap produktivitas kerja adalah disiplin kerja, motivasi kerja, upah kerja dan lingkungan kerja.

Penelitian ini bertujuan untuk mengetahui dan menganalisis : (1) pengaruh disiplin kerja terhadap produktivitas kerja, (2)pengaruh motivasi kerja terhadap produktivitas kerja, (3), pengaruh upah kerja terhadap produktivitas kerja, (4) pengaruh lingkungan kerja terhadap produktivitas kerja. Sampel penelitian ini adalah seluruh tenaga kerja di Unit Usaha Jasa Industri Dan Aneka Pangan Politeknik Negeri Jember yang berjumlah 19 orang. Data yang diperoleh dengan menggunakan kuisioner dengan metode sensus. Analisis data dilakukan dengan uji validitas, uji reliabilitas, linier berganda, koefisien korelasi, koefisien determinan, uji F dan uji t.

Hasil penelitian ini menunjukkan bahwa hipotesis (1) ditolak dengan probabilitas nilai $t=-0,150<$ 0,05, hal ini berarti disiplin kerja tidak berpengaruh secara signifikan terhadap produktivitas kerja. Hipotesis (2) ditolak dengan probabilitas nilai $t=0,116<0,05$, hal ini berarti motivasi kerja tidak berpengaruh secara signifikan terhadap produktivitas kerja.Hipotesis (3) ditolak dengan probabilitas nilai $t=1,863<0,05$, hal ini berarti upah kerja tidak berpengaruh secara signifikan terhadap produktivitas kerja. Hipotesis (4) diterima dengan probabilitas nilai $\mathrm{t}=2,121>0,05$ hal ini berarti lingkungan kerja berpengaruh secara signifikan dan positif terhadap produktivitas kerja. Disiplin kerja, motivasi kerja, upah kerja dan lingkungan kerja berkorelasi signifikan dan positif terhadap produktivitas kerja.

ABSTRAK

Suatu organisasi yang kompetitif memerlukan adanya dukungan dari seluruh sumber daya yang ada untuk meningkatkan kinerja dengan baik. Kajian empiris menyatakan bahwa faktor - faktor yang dapat mempengaruhi terhadap produktivitas kerja adalah disiplin kerja, motivasi kerja, upah kerja dan lingkungan kerja.

Penelitian ini bertujuan untuk mengetahui dan menganalisis : (1) pengaruh disiplin kerja terhadap produktivitas kerja, (2)pengaruh motivasi kerja terhadap produktivitas kerja, (3), pengaruh upah kerja terhadap produktivitas kerja, (4) pengaruh lingkungan kerja terhadap produktivitas kerja. Sampel penelitian ini adalah seluruh tenaga kerja di Unit Usaha Jasa Industri Dan Aneka Pangan Politeknik Negeri Jember yang berjumlah 19 orang. Data yang diperoleh dengan menggunakan kuisioner dengan metode sensus. Analisis data dilakukan dengan uji validitas, uji reliabilitas, linier berganda, koefisien korelasi, koefisien determinan, uji F dan uji t.

Hasil penelitian ini menunjukkan bahwa hipotesis (1) ditolak dengan probabilitas nilai $\mathrm{t}=$ $-0,150<0,05$, hal ini berarti disiplin kerja tidak berpengaruh secara signifikan terhadap produktivitas kerja. Hipotesis (2) ditolak dengan probabilitas nilai $\mathrm{t}=0,116<0,05$, hal ini berarti motivasi kerja tidak berpengaruh secara signifikan terhadap produktivitas kerja.Hipotesis (3) 
Kata Kunci : Disiplin Kerja, Motivasi Kerja, Upah Kerja, Lingkungan Kerja, Produktivitas

\section{PENDAHULUAN}

Peranan sektor pertanian dalam pembangunan nasional yang mencakup kegiatan peningkatan pendapatan dan kesejahteraan masyarakat, peningkatan produk domestik bruto, peningkatan devisa pengembangan industri dan industrialisasi pertanian. Peranan pendidikan serta pengembangan dan penerapan ilmu dan teknologi dalam pembangunan pertanian.

Unit Usaha Jasa Industri Dan Aneka Pangan merupakan salah satu unit kerja yang ada di lingkungan Politeknik Negeri Jember yang bertugas mengembangkan dan memasarkan produk roti dan aneka produk pangan memberikan layanan informasi kepada masyarakat tentang produk roti dan aneka produk pangan. Kegiatan program Unit Usaha Jasa Industri Dan Aneka Pangan Politeknik Negeri Jember itu penambahan sarana produksi, pengembangan produk, peningkatan produksi, peningkatan efektifitas dan efisiensi produksi serta pemasaran. Dengan penambahan investasi maka telah dilakukan peningkatan kapasitas produksi dan diversifikasi jenis roti yang diproduksi. Peningkatan produksi ditujukan untuk meningkatkan efisiensi dan efektifitas dalam berproduksi juga meningkatkan eksistensi produk di masyarakat. Sejalan upaya diversifikasi dan peningkatan kuantitas produksi, peningkatan kualitas produk juga dilakukan secara terus menerus. Selain optimasi formula produk, faktor tenaga kerja sangat menentukan kualitas produk roti .

Suatu organisasi dapat berjalan efektif apabila fungsi-fungsi manajemen seperti perencanaan, pengorganisasian, motivasi dan pengawasan yang ada didalamnya berfungsi dengan baik, serta unsur - unsur penunjangnya tersedia dan memenuhi persyaratan. Salah satu unsur terpenting yang dapat mendukung jalannya perusahaan adalah sumber daya manusia (karyawan). Sumber daya manusia mempunyai peranan penting dalam menentukan keberhasilan perusahaan. Kualitas Sumber Daya Manusia (SDM) adalah segalanya. Apa pun majunya peralatan pabrik dan besarnya modal yang dipakai kalau tidak dikelola oleh ahlinya, maka sumber daya tersebut akan tidak dikelola secara baik dan benar. Akibatnyta perusahaan akan merugi. OLeh karena itu tidak mengherankan kalau sekarang ini faktor SDM merupakan faktor yang diutamakan. Apalagi sekarang ini dalam Garis-Garis Besar Haluan Negara (GBHN) telah pula dituliskan bahwa aspek pengembangan sumber daya harus diperhatikan dalam setiap kegiatan pembangunan.

Salah satu faktor yang ikut menentukan tercapainya tujuan perusahaan adalah sumber daya manusia. Oleh karena itu perlu dilakukan perencanaan dan penanganan yang baik terhadap karyawan atau tenaga kerja. Dengan demikian dibutuhkan perhatian terhadap sumber daya menusia agar dapat memberikan suatu produktivitas yang optimal terhadap perusahaan atau industri terkait, tidak terkecuali dengan Unit Usaha Jasa Industri Dan Aneka Pangan Politeknik Negeri Jember. Dengan demikian produktivitas kerja merupakan salah satu faktor yang sangat berpengaruh terhadap kehidupan dalam suatu perusahaan. Produktivitas berasal dari kata "Produktif" artinya sesuatu yang mengandung potensi untuk digali, sehingga produktivitas dapatlah dikatakan sesuatu proses kegiatan yang terstruktur guna menggali potensi yang ada dalam sebuah komoditi atau objek. Filosofi produktivitas sebenarnya dapat mengandung arti keinginan dan usaha dari setiap manusia (individu atau kelompok) untuk selalu meningkatkan mutu kehidupannya dan penghidupannya. Secara umum produktivitas diartikan atau dirumuskan sebagai perbandingan antara hasil yang dicapai (output) dengan keseluruhan sumber daya yang digunakan (input). Dengan kata lain bahwa produktivitas memiliki dua dimensi. Dimensi pertama adalah efektifitas yang mengarah kepada pencapaian untuk kerja yang maksimal yaitu pencapaian target 
Endang WW, Wenny D dan Ratih P, Pengaruh Disiplin Kerja Motivasi Kerja, Upah Kerja Terhadap Produktivitas Kerja Di Unit Usaha Jasa Industri Dan Aneka Pangan Politeknik Negeri Jember

yang berkaitan dengan kualias, kuantitas, dan waktu. Dimensi kedua yaitu efisiensi yang berkaitan dengan upaya membandingkan input dengan realisasi penggunaannya atau bagaimana pekerjaan tersebut dilaksanakan.

Khusus permasalahan sumber daya manusia akan menentukan tingkat produktivitas yang dihasilkan. Banyak hal yang mempengaruhi produktivitas tenaga kerja Unit Usaha Jasa Industri Dan Aneka Pangan Politeknik Negeri Jember. Secara faktual banyak tenaga kerja yang tingkat produktivitasnya rendah dan banyak terjadi perputaran tenaga kerja (Labour Turnover), hal ini disebabkan oleh beberapa aspek. Aspek-aspek tersebut diantaranya adalah disiplin kerja, motivasi kerja, upah kerja dan lingkungan kerja yang selanjutnya akan diulas dalam penelitian ini. Dari industri ini terdapat banyak jumlah tenaga kerja yang sangat bervariasi tingkat kedisiplinan kerja, motivasi kerja, upah kerja dan lingkungan kerja yang berbeda. Dengan adanya hal tersebut maka peneliti mengambil langkah untuk memasukkan variabel disiplin kerja, motivasi kerja, upah kerja dan lingkungan kerja untuk dihubungkan dengan produktivitas kerja pada tenaga kerja Unit Usaha Jasa Industri Dan Aneka Pangan Politeknik Negeri Jember.

Tabel 1

Data Produksi tahun 2006-2010

\begin{tabular}{|c|c|c|c|c|c|c|}
\hline \multirow{2}{*}{$\mathrm{No}$} & \multirow{2}{*}{ Jenis produk } & \multicolumn{5}{|c|}{ Tahun (bungkus) } \\
\hline & & 2006 & 2007 & 2008 & 2009 & 2010 \\
\hline 1 & Roti tawar & 71.493 & $|3.23|$ & 12.254 & 11.935 & 4.863 \\
\hline 2 & Rati Manis & 36.08 & 9.274 & 15.346 & 21.993 & 17.734 \\
\hline 3 & Roti kasur & 2.267 & 1.058 & 2.61 & 2.932 & 1.058 \\
\hline 4 & Rati Sabek & 2.394 & 2.314 & 2.480 & 2.014 & 238 \\
\hline 5 & Rati sisir & 3.58 & - & 1.078 & 529 & I.DI6 \\
\hline 6 & Roti Walker & - & & 1.592 & - & - \\
\hline 7 & Rati Bagelan & 1.573 & 863 & 817 & 891 & 389 \\
\hline 8 & Rati Kering & 6.574 & 404 & 5.608 & 4.914 & 623 \\
\hline 9 & Donat & 11.883 & 84 & 29 & - & - \\
\hline 10 & Pesanan & - & 9.298 & 13.983 & 14.294 & 6.612 \\
\hline
\end{tabular}

\section{METODOLOGI}

\section{Rancangan Penelitian}

Rancangan penelitian ini adalah penelitian survey. Penelitian survey adalah penelitian yang mengambil sampel dari suatu populasi dan menggunakan kuesioner sebagai alat pengumpulan data yang pokok (Singarimbun dan Effendi, 1995).

\section{Populasi Penelitian,Besar dan Teknik Pengambilan Sampel \\ Populasi adalah keseluruhan subyek} penelitian. Apabila seseorang ingin meneliti semua elemen yang berada dalam wilayah penelitian, penelitian yang dilakukan adalah penelitian populasi. Sedangkan sampel adalah jika seseorang hanya akan meneliti sebagian dari populasi maka penelitian tersebut disebut penelitian sampel. Sampel adalah sebagian atau wakil populasi yang diteliti. Dinamakan sampel bila peneliti bermaksud untuk menggeneralisasikan hasil penelitian sampel (Arikunto,2010)

Apabila peneliti ingin meneliti semua elemen yang ada dalam wilayah penelitian maka penelitiannya merupakan penelitian populasi, studi penelitiannya disebut studi populasi atau studi sensus (Arikunto,2010). Pertimbangan menggunakan semua elemen yang ada dalam wilayah penelitian untuk mendapatkan gambaran yang lebih representatif dan mengurangi tingkat kesalahan data yang diperoleh mendekati nilai sesungguhnya. Populasi dalam penelitan ini adalah seluruh karyawan yang ada di Unit Usaha Jasa Industri Dan Aneka Pangan Politeknik Negeri Jember yang berjumlah 19 orang.

\section{Variabel Penelitian}


Ada beberapa variabel yang digunakan dalam melakukan penelitian ini, diantaranya adalah :

\section{Klasifikasi Variabel}

Berdasarkan kerangka konseptual, variabel di dalam penelitian ini dapat diklasifikasikan sebagai berikut :

1. Disiplin kerja sebagai variabel independent pertama (X1) yang dapat mempengaruhi produktivitas kerja pada Unit Usaha Jasa Industri Dan Aneka Pangan Politeknik Negeri Jember.

2. Motivasi kerja sebagai variabel independent kedua (X2) yang dapat mempengaruhi produktivitas kerja pada Unit Usaha Jasa Industri Dan Aneka Pangan Politeknik Negeri Jember.

3. Upah kerja sebagai variabel independent ketiga (X3) yang dapat mempengaruhi produktivitas kerja pada Unit Usaha Jasa Industri Dan Aneka Pangan Politeknik Negeri Jember.

4. Lingkungan kerja sebagai variabel independent keempat (X4) yang dapat mempengaruhi produktivitas kerja pada Unit Usaha Jasa Industri Dan Aneka Pangan Politeknik Negeri Jember

5. Produktivitas kerja sebagai variabel dependent (Y) yang dipengaruhi oleh variabel independent disiplin kerja (X1), variabel independent motivasi kerja (X2), variabel independent upah kerja (X3), variabel independent lingkungan kerja (X4), di Unit Usaha Jasa Industri Dan Aneka Pangan Politeknik Negeri Jember.

\section{Definisi Operasional Variabel}

Menurut Masri Singarimbun dan Sofyan Effendi (1995) salah satu unsur yang sangat membantu komunikasi antara peneliti adalah definisi operasional yang merupakan petunjuk tentang bagaimana variabel diukur. Dengan membaca definisi operasional dalam suatu penelitian, seorang peneliti akan mengetahui pengukuran suatu variabel sehingga dapat mengetahui baik buruknya pengetahuan tersebut. Berdasarkan pengertian definisi operasional di atas maka kesimpulan penulis tentang definisi operasional adalah pengukuran konsep yang abstrak teoritis menjadi kata - kata tentang tingkah laku atau gejala yang dapat diamati, dapat diuji dan dapat ditentukan kebenarannya oleh orang lain.

Definisi operasional dalam penelitian adalah :

1. Disiplin Kerja (X1)

Disiplin Kerja sebagai variabel bebas

dengan indikator sebagai berikut : a. Masuk kerja tepat waktu (X1.1)

b. Mentaati instruksi kerja supervisor (X1.2)

c. Menyelesaikan pekerjaan dengan penuh tanggung jawab (X1.3)

d. Mentaati peraturan yang berlaku(X1.4)

e. Menghindari perkelahian, mabuk dan pencurian $(\mathrm{X} 1.5)$

2. Motivasi Kerja (X2)

Motivasi sebagai variabel bebas

dengan indikator sebagai berikut :

a. Kebutuhan fisiologis (X2.1)

b. Harapan rasa nyaman (X2.2)

c. Kebutuhan sosial (X2.3)

d. Kebutuhan akan penghargaan (X2.4)

e. Kebutuhan aktualisasi diri (X2.5)

3. Upah (X3)

Upah sebagai variabel bebas (X3) dengan indikator sebagai berikut :

a. Upah yang diterima saat ini (X3.1)

b. Tingkat kesesuaian upah dan beban kerja (X3.2)

c. Upah sesuai dengan kesepakatan dan perjanjian (X3.3)

d. Upah yang sesuai dengan kebutuhan hidup (perhari) (X3.4)

4. Lingkungan Kerja (X4)

Lingkungan kerja sebagai variabel bebas

(X4) dengan indikator sebagai berikut :

a. Pemenuhan rasa nyaman dan aman di lingkungan kerja yang dirasakan pekerja saat beraktivitas (X4.1)

b. Pemenuhan rasa aman dari fasilitas yang digunakan pekerja saat beraktivitas (X4.2)

c. Perasaan senang selama menyelesaikan pekerjaan harian (X4.3)

d. Perasaan akrab dengan para pekerja yang lain (X4.4)

5. Produktivitas kerja karyawan (Y)

Produktivitas kerja sebagai variabel tidak bebas

(Y) dengan indikator sebagai berikut :

a. Bekerja selalu memenuhi atau sesuai dengan target yang telah diberikan

b. Senang apabila pekerjaan sudah sesuai dengan target yang ditetapkan oleh atasan

c. Selama bekerja selalu mampu menyelesaikan semua pekerjaan yang telah diberikan

\section{Instrumen Penelitian}

Sesuai dengan rumusan masalah, tujuan penelitian dalam penelitian ini digunakan instrument penelitian dalam bentuk kuesioner untuk memperoleh data - data penelitian tentang faktor - faktor yang mempengaruhi produktivitas tenaga kerja di Unit Usaha Jasa Industri Dan Aneka Pangan Politeknik Negeri Jember. 
Endang WW, Wenny D dan Ratih P, Pengaruh Disiplin Kerja Motivasi Kerja, Upah Kerja Terhadap Produktivitas Kerja Di Unit Usaha Jasa Industri Dan Aneka Pangan Politeknik Negeri Jember

Menurut Arikunto (2010), kuesioner adalah sejumlah pertanyaan tertulis yang digunakan untuk memperoleh informasi dari responden dalam arti laporan tentang pribadinya, atau hal-hal yang dia ketahui. Kuesioner ini sering juga disebut sebagai angket.

\section{Lokasi Penelitian}

Penelitian ini akan dilaksanakan di Unit Usaha Jasa Industri Dan Aneka Pangan yang berlokasi di Jl. Mastrip PO. BOX 164 Politeknik Negeri Jember. Penentuan lokasi dilakukan secara sengaja (purposive) atas dasar pertimbangan bahwa lokasi ini merupakan Agroindustri pada sektor pertanian yang masih berpotensi untuk dikembangkan lebih luas. Selain itu lokasi Unit Usaha Jasa Industri Dan Aneka Pangan Politeknik Negeri Jember tergolong strategis.

\section{Prosedur Pengumpulan Data}

Data yang diperoleh dalam penelitian ini adalah data primer yaitu data yang diperoleh langsung dari sumbernya. Dalam penelitian ini data primer diperoleh langsung dari lokasi penelitian melalui dua metode :

1. Kuesioner
Kuesioner adalah suatu pengumpulan data dengan perangkat pertanyaan tertutup yang diajukan pada responden untuk meminta pendapat responden tentang suatu permasalahan.

2. Wawancara

Wawancara dilakukan dengan bertanya langsung pada sumber daya manusia yang dianggap banyak memiliki informasi yang berhubungan dengan obyek penelitian. Hal ini untuk membandingkan dengan data yang diperoleh melalui kuesioner.

\section{HASIL DAN PEMBAHASAN}

\section{Hasil Uji Validitas dan Reliabilitas}

Menurut (Arikunto, 2010), instrumen dikatakan valid jika instrumen yang digunakan dapat mengukur apa yang hendak diukur. Tinggi rendahnya validitas instrumen menunjukkan sampai sejauh mana data yang dikumpulkan tidak menyimpang dari gambaran tentang variabel yang diteliti. Dalam survai uji validitas dilakukan dengan mengkorelasikan skor setiap item dengan total skor. Item pertanyaan yang mempunyai korelasi positif dengan total skor serta korelasinya tinggi, menunjukan bahwa item tersebut mempunyai validitas tinggi pula dimana $r_{\text {hitung }}>r$ tabel. Oleh karena itu jika $r_{\text {hitung }}<r_{\text {tabel }}$ maka butir dalam instrumen tersebut kurang valid (Sugiyono, 2010). Hasil uji validitas secara ringkas disajikan pada Tabel 2 sebagai berikut:

Tabel 2

Hasil Uji Validitas

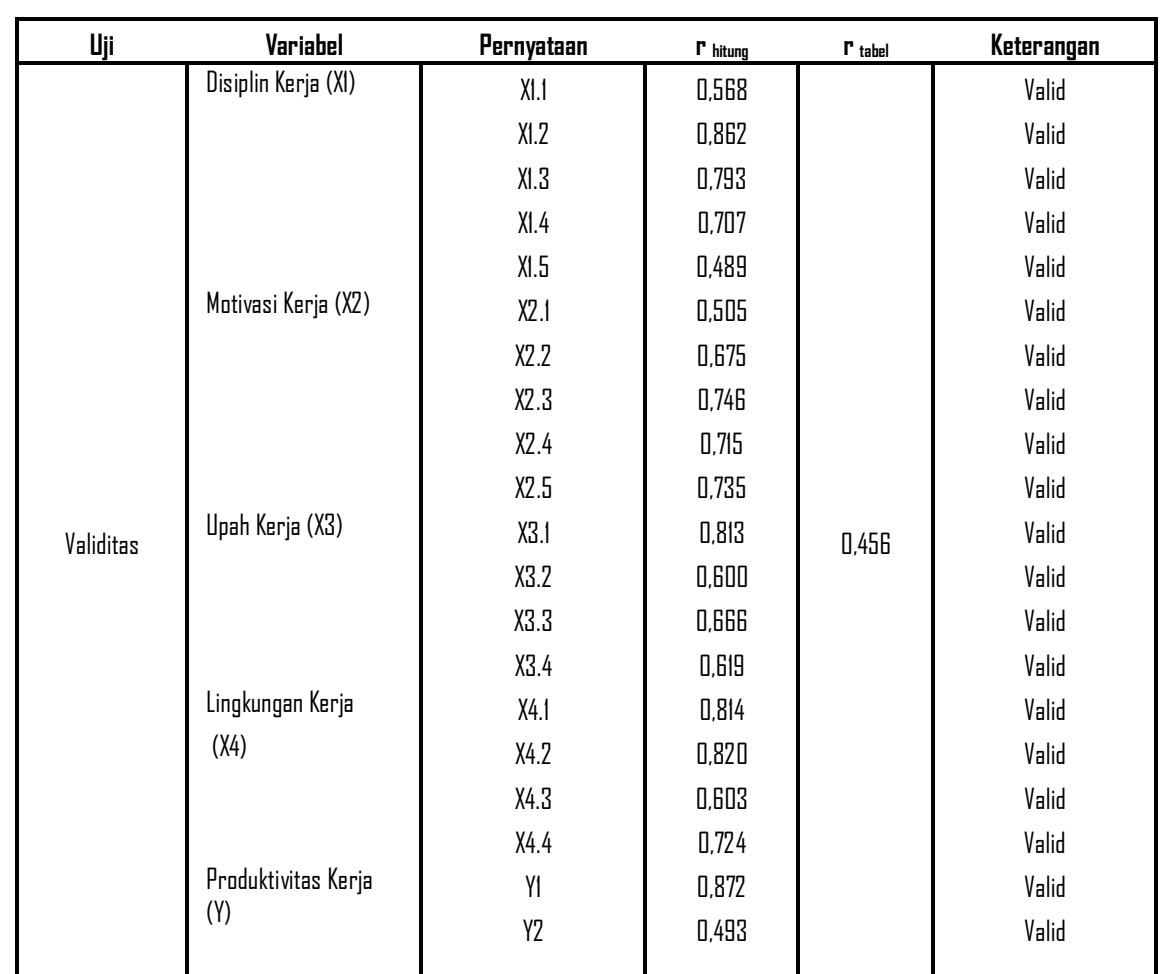


Dari Tabel 2 dapat dilihat bahwa semua instrumen memiliki nilai $r$ hitung lebih besar dari nilai $r_{\text {tabel }(n=19, r=5 \%)} 0,456$. Berdasarkan kriteria uji validitas jika $r$ hitung lebih besar dari atau sama dengan nilai $\mathrm{r}_{\text {tabel }}\left(\mathrm{r}_{\text {hitung }} \geq \mathrm{r}\right.$ tabel) pada level of significance $(\alpha=0,05)$ berarti instrumen tersebut telah memenuhi kriteria validitas.

Menurut Arikunto (2010), reliabilitas sama dengan konsistensi atau keajekan. Suatu instrumen penelitian dikatakan mempunyai nilai reliabilitas yang tinggi apabila tes yang dibuat mempunyai hasil yang konsisten dalam mengukur yang hendak

Tabel 3

Hasil Uji Reliabilitas

\begin{tabular}{ccc} 
& \multicolumn{3}{c}{ Nilai $\mathbf{r}$} \\
tabel \\
$\begin{array}{c}\text { Pengujian } \\
\text { Spearman } \\
\text { Brown }\end{array}$ & $\begin{array}{c}\text { (n=19, } \\
\mathbf{a = 5 \%})\end{array}$ & Kesimpulan \\
\hline 0,802 & 0,456 & Reliabel \\
\hline
\end{tabular}

Dari Tabel 3 dapat dilihat bahwa nilai pengujian Spearman Brown lebih besar nilai $\mathrm{r}$ tabel pada taraf signifikan 0,05 (5\%). Berdasarkan kriteria uji reliabilitas jika nilai pengujian Spearman Brown lebih besar dari atau sama dengan nilai $\mathrm{r}_{\text {tabel }}\left(\mathrm{r}_{\text {hitung }} \geq \mathrm{r}\right.$ tabel $)$ pada level of significance $(\alpha=0,05)$ berarti instrumen tersebut telah memenuhi kriteria reliabilitas.

\section{Analisis Regresi Linier Berganda}

Analisis hasil penelitian yang dilakukan terhadap 19 responden karyawan Unit Usaha Jasa diukur. Instrumen dikatakan reliabel adalah instrumen yang jika digunakan beberapa kali dalam waktu yang berbeda untuk mengukur obyek yang sama akan menghasilkan data yang sama (Sugiyono, 2010). Instrumen dapat dikatakan reliabel jika nilai reliabilitas dalam rumus Spearman Brown lebih besar dari $\mathrm{r}_{\text {tabel }}$ pada level of significance $(\alpha=0,05)$. Hasil uji reliabilitas secara lengkap disajikan pada Lampiran 5 dan secara ringkas disajikan pada Tabel 3 sebagai berikut: 
Berdasarkan Tabel 4 maka diperoleh persamaan regresi sebagai berikut:

$\mathrm{Y}=1,998-0,020 \mathrm{X} 1+0,014 \mathrm{X} 2+0,317 \mathrm{X} 3+0,317$ $\mathrm{X} 4$

Persamaan regresi linear berganda di atas secara terperinci dapat dijelaskan sebagai berikut:

1. Nilai konstanta sebesar 1,998

Konstanta bernilai positif berarti jika ada variabel Disiplin Kerja (X1), Motivasi Kerja (X2), Upah Kerja (X3) dan Lingkungan Kerja (X4) maka nilai variabel Produktivitas Kerja (Y) akan mengalami peningkatan sebesar 1,998. Ini berarti jika variabel Disiplin Kerja, Motivasi Kerja , Upah Kerja, dan Lingkungan Kerja memiliki nilai 0 (nol), maka Produktivitas Kerja karyawan Unit Usaha Jasa Industri Dan Aneka Pangan Politeknik Negeri Jember adalah sebesar 1,998.

2. Nilai koefisien variabel Disiplin Kerja (X1) sebesar - 0,020

Koefisien variabel Disiplin Kerja (X1) menunjukkan adanya pengaruh negatif terhadap variabel Produktivitas Kerja (Y). Hal ini berarti apabila variabel Disiplin Kerja (X1) berkurang (karena tanda-) sebesar 1 tingkat, maka akan mengakibatkan penurunan Produktivitas Kerja (Y) sebesar 0,020 dengan asumsi variabel Motivasi Kerja (X2), Upah Kerja (X3) dan Lingkungan Kerja (X4) dianggap tetap (konstan).

3. Nilai koefisien variabel Motivasi Kerja (X2) sebesar 0,014

Koefisien variabel Motivasi Kerja (X2) menunjukkan adanya pengaruh positif terhadap variabel Produktivitas Kerja (Y). Hal ini berarti apabila variabel Motivasi Kerja (X2) bertambah sebesar 1 tingkat, maka akan mengakibatkan peningkatan Produktivitas
Kerja (Y) sebesar 0,014 dengan asumsi variabel Disiplin Kerja (X1), Upah Kerja (X3) dan Lingkungan Kerja (X4) dianggap tetap (konstan)

4. Nilai koefisien variabel Upah Kerja (X3) sebesar 0,317

Koefisien variabel Upah Kerja (X3) menunjukkan adanya pengaruh positif terhadap variabel Produktivitas Kerja (Y). Hal ini berarti apabila variabel Upah Kerja (X3) bertambah sebesar 1 tingkat, maka akan mengakibatkan peningkatan Produktivitas Kerja (Y) sebesar 0,317 dengan asumsi variabel Disiplin Kerja (X1), Motivasi Kerja (X2) dan Lingkungan Kerja (X4) dianggap tetap (konstan)

5. Nilai koefisien variabel Lingkungan Kerja (X4) sebesar 0,317

Koefisien variabel Lingkungan Kerja (X4) menunjukkan adanya pengaruh positif terhadap variabel Produktivitas Kerja (Y). Hal ini berarti apabila variabel Lingkungan Kerja (X4) bertambah sebesar 1 tingkat, maka akan mengakibatkan peningkatan Produktivitas Kerja (Y) sebesar 0,317 dengan asumsi variabel Disiplin Kerja (X1), Motivasi Kerja (X2) dan Upah Kerja (X3) dianggap tetap (konstan)

\section{Analisis Koefisien Korelasi}

Koefisien Korelasi (R) dipergunakan untuk mengetahui kekuatan hubungan komponen variabel bebas Disiplin Kerja (X1), Motivasi Kerja (X2), Upah Kerja (X3) dan Lingkungan Kerja (X4) terhadap variabel terikat Produktivitas Kerja (Y). Hasil perhitungan analisis koefisien korelasi melalui SPSS 16.00 for windows dapat dilihat pada Tabel 5 sebagai berikut :

Tabel 5

Hasil Analisis Koefisien Korelasi Dari Pengaruh Disiplin Kerja, Motivasi Kerja, Upah Kerja dan Lingkungan Kerja terhadap Variabel Produktivitas Kerja

\begin{tabular}{|c|c|c|c|c|}
\hline Model & $\mathrm{R}$ & R Square & Adjusted R Square & Std. Error of the Estimate \\
\hline 1 & $.766^{\mathrm{a}}$ & .587 & .469 & .724 \\
\hline
\end{tabular}


Berdasarkan Tabel 5 diperoleh nilai koefisien korelasi (R) sebesar 0,766. Koefisien korelasi sebesar 0,766 tersebut menunjukkan bahwa hubungan variabel bebas yaitu Disiplin Kerja (X1), Motivasi Kerja (X2), Upah Kerja (X3) dan Lingkungan Kerja (X4) terhadap variabel terikat Produktivitas Kerja (Y) dikategorikan cukup kuat karena besarnya koefisien korelasi tersebut diantara 0,76-0,90. Penulis menggunakan pedoman interpretasikan koefisien oleh Supranto (1997) sebagai berikut:

Tabel 6

Pedoman Interpretasi Koefisien Korelasi

\begin{tabular}{|c|c|}
\hline Interval Koefisien & Tingkat Hubungan \\
\hline $0,00-0,50$ & Sangat rendah \\
$0,51-0,75$ & Rendah \\
$\mathbf{0 , 7 6}-\mathbf{0 , 9 0}$ & Cukup kuat \\
$0,91-0,99$ & Kuat \\
$=1,00$ & Sangat kuat \\
\hline
\end{tabular}

\section{Analisis Koefisien Determinasi Berganda}

Koefisien determinasi berganda digunakan untuk mengetahui besarnya pengaruh variabel bebas terhadap variabel terikat atau besarnya kontribusi variabel bebas yaitu Disiplin Kerja (X1), Motivasi Kerja (X2), Upah Kerja (X3) dan Lingkungan Kerja (X4) terhadap variabel terikat Produktivitas Kerja (Y). Hasil perhitungan analisis koefisien determinasi berganda melalui SPSS 16.00 for windows dapat dilihat pada Tabel 5.

Berdasarkan Tabel 5 diperoleh nilai koefisien determinasi $\mathrm{R}^{2}$ sebesar 0,469 atau 46,9\%. Hal ini berarti bahwa 46,9\% perubahan variabel terikat yaitu Produktivitas Kerja (Y) disebabkan oleh perubahan variabel bebas yaitu Disiplin Kerja (X1), Motivasi Kerja (X2), Upah Kerja (X3) dan Lingkungan Kerja (X4) sedangkan sisanya sebesar 0,531 atau $53,1 \%$ disebabkan oleh faktor lain yang tidak termasuk dalam model.

Hasil analisis data yang diperoleh dalam penelitian yang dilakukan di Unit Usaha Jasa Industri Dan Aneka Pangan Politeknik Negeri Jember, dengan judul Penelitian "Pengaruh Disiplin Kerja, Motivasi Kerja, Upah Kerja dan Lingkungan Kerja Terhadap Produktivitas Kerja di Unit Usaha Jasa Industri Dan Aneka Pangan Politeknik Negeri Jember" diketahui bahwa nilai perhitungan regresi linier berganda sebagai berikut:

$\mathrm{Y}=1,998-0,020 \mathrm{X} 1+0,014 \mathrm{X} 2+0,317 \mathrm{X} 3+$ $0,317 \mathrm{X} 4$

Menunjukkan apabila tidak ada faktor disiplin kerja ( X1), motivasi kerja (X2), upah kerja (X3) dan lingkungan kerja (X4) maka nilai produktivitas kerja karyawan (Y) akan tetap. Hal ini berarti bahwa jika variabel bebas $(\mathrm{X} 1, \mathrm{X} 2, \mathrm{X} 3, \mathrm{X} 4)$ sama dengan 0 (nol) maka variabel terikat (Y) adalah sebesar 1,998. Besarnya nilai konstanta menunjukkan nilai yang positif, hal ini berarti bahwa adanya pengaruh positif terhadap produktivitas kerja karyawan apabila variabel disiplin kerja, motivasi kerja, upah kerja dan lingkungan kerja konstan atau tetap.

Koefisien korelasi adalah tingkat hubungan keeratan antara variabel bebas terhadap variabel terikat. Nilai koefisien korelasi (R) yang diperoleh dari hasil analisis data adalah sebesar 0,766, berdasarkan ketentuan (Supranto,1997) hubungan antara varibel bebas dan varibel terikat termasuk dalam kategori cukup kuat. Besarnya prosentase hubungan varibel bebas $(\mathrm{X})$ terhadap varibel terikat (Y) terlihat pada nilai Adjusted R square yaitu 0,469 atau sebesar 46,9 \% keseluruhan variabel bebas dalam penelitian ini berpengaruh terhadap variabel terikat, sedangkan sisanya sebesar 53,1\% dipengaruhi oleh faktor lain diluar varibel penelitian yang dilakukan oleh peneliti. Hal ini berarti naik turunnya produktivitas kerja ikut dipengaruhi oleh faktor disiplin kerja, motivasi kerja, upah kerja dan lingkungan kerja. Guna menguji signifikansi secara serempak dari persamaan regresi berganda yang diperoleh tersebut digunakan uji $\mathrm{F}$, dari hasil analisis data, diperoleh bahwa nilai $F_{\text {hitung }}$ sebesar 4,978 sedangkan $\mathrm{F}_{\text {table }}$ diperoleh dari derajat kebebasan (dk) pembilang $=4 \mathrm{dan} \mathrm{dk}$ penyebut $=14$ adalah sebesar 3,11 artinya bahwa $F_{\text {hitung }}>F_{\text {table yaitu }}$ 4,978> 3,11. Hasil tersebut menyatakan bahwa secara serentak (simultan) varibel bebas (X) berpengaruh signifikan terhadap variabel bebas (Y).

Pengaruh secara parsial masing-masing variabel bebas terhadap variabel terikat dapat diketahui dari uji signifikan secara parsial (uji t). Dari perhitungan hasil analisis data yang diperoleh diketahui bahwa nilai varibel disiplin kerja (X1) adalah sebesar $-0,150$. Diketahui bahwa nilai $t_{\text {hitung }}$ $<\mathrm{t}_{\text {table }}(-0,150<2,11)$ yang artinya bahwa secara parsial tidak terdapat pengaruh yang signifikan antara disiplin kerja terhadap produktivitas tenaga kerja. Maka hasil penelitian ini secara parsial tidak konsisten dengan penelitian sebelumnya seperti penelitian yang dilakukan oleh Andreas 
(2010), Zaenal (2008), Dwi Kusumawarni (2007), Prasojo (2007), Ani Fauziyah (2005), Nana Ismanta (2004) disebabkan penelitian sebelumnya dilakukan pada tempat yang berbeda, skala usaha (perusahaan), sifat usaha, objek yang berbeda dan karakteristik pengusaha ini sendiri tidak melakukan peraturan yang tertulis maupun tidak tertulis hanya diharapkan dari kesadaran setiap pekerja sendiri dalam bekerja.

Sedangkan nilai t hitung motivasi kerja (X2) adalah sebesar 0,116 yang artinya bahwa $\mathrm{t}_{\text {hitung }}<\mathrm{t}_{\text {table }}(0,116<2,11)$ secara parsial motivasi kerja tidak berpengaruh signifikan terhadap produktivas tenaga kerja. Penelitian ini tidak konsisten dengan penelitian sebelumnya seperti penelitian yang dlakukan oleh Adjuta (2010), Zaenal (2008), Farida (2007), Prasojo (2007) disebabkan penelitian sebelumnya dilakukan pada tempat yang berbeda, skala usaha (perusahaan), sifat usaha, objek yang berbeda dan karakteristik pengusaha ini sendiri tidak melakukan peraturan yang tertulis maupun tidak tertulis hanya diharapkan dari kesadaran setiap pekerja sendiri dalam bekerja.

Nilai t hitung upah kerja (X3) adalah 1,863 yang artinya bahwa $\quad t_{\text {hitung }}<t_{\text {table }}$ $(1,863<2,11)$ secara parsial upah kerja tidak berpengaruh signifikan terhadap produktivitas kerja, maka hasil penelitian ini secara parsial konsisten dengan penelitian sebelumnya seperti penelitian yang dilakukan oleh Reftia (2011), Winarni (2005). Penelitian sebelumnya menyatakan bahwa secara parsial variabel upah kerja tidak berpengaruh signifikan terhadap produktivitas tenaga kerja bagian pengolahan kopi robusta di PTPN XII Kebun Silosanen Jember (Reftia, 2011). Penelitian sebelumnya menyatakan bahwa secara parsial variabel upah kerja tidak berpengaruh signifikan terhadap produktivitas tenaga kerja bagian cerutu pada koperasi karyawan Kartanegara PTPN (Persero) Desa Candidjati Kecamatan Arjasa Kabupaten Jember (Winarni, 2005).

Nilai $t_{\text {hitung lingkungan kerja sebesar }}$ 2,121 yang artinya bahwa $t_{\text {hitung }}>t_{\text {table }}$ $(2,121>2,11)$, secara parsial lingkungan kerja berpengaruh signifikan terhadap produktivitas kerja, maka hasil penelitian ini secara parsial konsisten dengan penelitian sebelumnya seperti penelitian yang dilakukan oleh Wulan (2011), Istikomah (2009), Prasojo (2007). Penelitian sebelumnya menyatakan bahwa secara parsial variabel lingkungan kerja berpengaruh signifikan terhadap produktivitas tenaga kerja Afdeling Di PTPN XII (Persero) Kebun Kotta Blater JemberJawa Timur (Wulan, 2011). Penelitian sebelumnya menyatakan bahwa secara parsial variabel lingkungan kerja berpengaruh signifikan terhadap produktivitas tenaga kerja langsung pada CV. Rimba Sentosa Di Tawangsari Kabupaten Sukoharjo (Istikomah, 2009). Penelitian sebelumnya menyatakan bahwa secara parsial variabel lingkungan kerja berpengaruh signifikan terhadap produktivitas kerja karyawan pada perusahaan mebel CV. Yudhistira Kartasura Sukoharjo (Prasojo, 2007).

Dari hasil pengujian yang dilakukan secara parsial, produktivitas kerja pada Unit Usaha Jasa Industri Dan Aneka Pangan Politeknik Negeri Jember dipengarui oleh lingkungan kerja atau (X4) sedangkan untuk ketiga variabel lain yaitu disiplin kerja X1), motivasi kerja (X2), dan upah kerja (X3) tidak mempengaruhi produktivitas tenaga kerja.

\section{Kesimpulan}

Berdasarkan hasil analisis data dan pembahasan yang diperoleh dari data penelitian yang dilaksanakan di Unit Usaha Jasa Industri Dan Aneka Pangan Politeknik Negeri Jember menunjukan bahwa:

1. Secara bersama-sama simultan varibel bebas disiplin kerja (X1), motivasi kerja (X2), upah kerja (X3) dan lingkungan kerja (X4) berpengaruh signifikan terhadap variabel terikat, prduktivitas kerja yang ditunjukan bahwa $\mathrm{F}_{\text {hitung }}$ $(4,978)>F_{\text {tabel }}(3,11)$ pada level of significance $0,05(\alpha=0,05)$.

2. Variabel bebas Disiplin Kerja (X1) memiliki nilai thitung sebesar -0,150 lebih kecil dari $t_{\text {tabel }}$ sebesar $\left(t_{\text {hitung }}<t_{\text {tabel }}\right)$ dan memiliki nilai probabilitas lebih besar dari level of significance $(\alpha=0,05)$ yaitu sehingga variabel Disiplin Kerja (X1) tidak berpengaruh signifikan secara parsial terhadap Produktivitas Kerja (Y).

3. Variabel bebas Motivasi Kerja (X2) memiliki nilai $t_{\text {hitung }}$ sebesar 0,116 lebih kecil dari $t_{\text {tabel }}$ sebesar $\left(t_{\text {hitung }}<t_{\text {tabel }}\right)$ dan memiliki nilai probabilitas lebih besar dari level of significance $(\alpha=0,05)$ yaitu sehingga variabel Motivasi Kerja (X2) tidak berpengaruh signifikan secara parsial terhadap Produktivitas Kerja (Y).

4. Variabel bebas Upah Kerja (X3) memiliki nilai $t_{\text {hitung }}$ sebesar 1,863 lebih kecil dari $\mathrm{t}_{\text {tabel }}$ sebesar ( $\mathrm{t}_{\text {hitung }}<\mathrm{t}_{\text {tabel }}$ ) dan memiliki nilai probabilitas lebih besar dari level of significance $(\alpha=0,05)$ yaitu sehingga variabel Upah Kerja (X3) tidak berpengaruh signifikan secara parsial terhadap Produktivitas Kerja (Y).

5. Variabel bebas Lingkungan Kerja (X4) memiliki nilai thitung sebesar 2,121 lebih 
Endang WW, Wenny D dan Ratih P, Pengaruh Disiplin Kerja Motivasi Kerja, Upah Kerja Terhadap Produktivitas Kerja Di Unit Usaha Jasa Industri Dan Aneka Pangan Politeknik Negeri Jember

besar dari $t_{\text {tabel }}$ sebesar $\left(t_{\text {hitung }}>t_{\text {tabel }}\right)$ dan memiliki nilai probabilitas lebih kecil dari level of significance $(\alpha=0,05)$ yaitu sehingga variabel Lingkungan Kerja (X4) berpengaruh signifikan secara parsial terhadap Produktivitas Kerja (Y).

\section{DAFTAR PUSTAKA}

Andreas, 2010. Pengaruh Pengawasan Kerja Dan Disiplin Kerja Terhadap Produktivitas Kerja Karyawan Bagian Produksi PTPN XII Kebun Silosanen Jember - Jawa Timur. Jember : Politeknik Negeri Jember.

Arifin Z, 2008. Pengaruh Motivasi Dan Disiplin Kerja Terhadap Produktivitas Kerja Karyawan Di Pt. Adi Bungsu Malang. Malang: Universitas Negeri Malang.

Arikunto, S. 2010. Manajemen Penelitian. Jakarta : RINEKA CIPTA, Jakarta.

Arikunto, S. 2010. Prosedur Penelitian Suatu Pendekatan Praktek (Edisi Revisi V). Jakarta : RINEKA CIPTA, Jakarta.

Atmuharyani. 2010. Pengaruh Upah Dan Usia Terhadap Produktivitas Tenaga Kerja Harian Pada Pengolahan Karet Lembaran Di PTPN XII Kebun Renteng Kabupaten Jember. Jember : Politeknik Negeri Jember.

Farida, E. 2007. Kajian Motivasi dan Produktivitas Tenaga Kerja Wanita Pada Perusahaan Jamu Dayang Sumbi. Skripsi. Jember : Fakultas Pertanian Universitas Jember.

Fauziyah A, 2005. Pengawasan Kerja Dan disiplin Kerja Terhadap Produktivitas Kerja Karyawan Bagian Produksi Perlintingan Di Perusahaan Rokok Kretek Sukun MC. Wartono Kudus. Semarang : Universitas Negeri Semarang.

Hariandja, M, T. E. 2009. Manajemen Sumber Daya Manusia. Jakarta : Grasindo.

Ismanta N, 2004. Pengaruh Pengalaman Kerja Dan Disiplin Kerja Terhadap Produktivitas Kerja Karyawan Perusahaan Speaker Aktif Elektronika Di Desa Gribig Kecamatan Gebog Kabupaten Kudus. Semarang : Universitas Negeri Semarang.
Istikomah, 2009. Pengaruh Upah Dan Lingkungan Kerja Terhadap Produktivitas Tenaga Kerja Langsung Pada CV. Rimba Sentosa Di Tawangsari Kabupaten Sukoharjo. Surakarta : Universitas Muhammadiyah Surakarta.

Kusumawarni D, 2007. Pengaruh Semangat Dan Disiplin Kerja Terhadap Produktivitas Kerja Karyawan Pada Perusahaan Daerah Air Minum (PDAM) Kabupaten Kudus. Semarang : Universitas Negeri Semarang.

Laily, 2011. Pengaruh Upah, Tingkat Pendidikan, Usia Terhadap Produktivitas Tenaga Kerja Bagian Pabrik Pada PT. Benih Citra Asia Kebupaten Jember, Jember : Politeknik Negeri Jember.

Mangkunegara, A 2009. Manajemen Sumber Daya Manusia Perusahaan. Bandung : Remaja Rosdakarya.

Mangkuprawira, S. Tb. 2003. Manajemen Sumber Daya Manusia Strategik. Jakarta : Ghalia Indonesia.

Mulyadi. 2001. Sistem Akuntansi. Jakarta : Salemba Empat.

Panggabean, MS. 2002. Manajemen Sumber Daya Manusia, Jakarta: Gahlia Indonesia.

Prabhaswara A, 2009. Pengaruh Motivasi Dan Pengawasan Kerja Terhadap Produktivitas Kerja Karyawan Dinas Pasar Pemerintah Kota Surakarta. Surakarta : Universitas Muhammadiyah Surakarta.

Reftia, 2011. Pengaruh Upah Dan Masa Kerja Terhadap Produktivitas Tenaga Kerja Bagian Pengolahan Kopi Robusta, Jember : Politeknik Negeri Jember.

Sandi P, 2007. Pengaruh Disiplin Kerja, Lingkungan Kerja Dan Motivasi Kerja Terhadap Produktivitas Kerja Karyawan Pada Perusahaan Mebel CV. Yudhistira Kartasura. Universitas Muhammadiyah Surakarta.

Siagian Sondang P. 2002. Kiat Meningkatkan Produktivitas Kerja. Jakarta : Rineka Cipta. 
Jurnal Ilmiah INOVASI, Vol.13 No.1, Hal. 1-10, Januari-April 2013, ISSN 1411-5549

Singarimbun, M. dan S. Effendi. 1995. Metode Penelitian Survei. Jakarta. Pustaka LP3ES Indonesia.

Sudarmayanti. 1996. Tata Kerja Dan Produktivitas Kerja : Kaitan Antara Manusia dan lingkungan. Bandung : Mandar Maju.

Sugiyono, 2010. Statistik Nonparametris. Bandung : Alfabeta

Sugiyono. 2009. Statistik Untuk Penelitian. Bandung : Alfabeta.

Sukardi, Ph. D. 2009. Metodologi Penelitian Pendidikan. Jakarta : Bumi Angkasa

Supranto, 1997. Metode Riset. Jakarta : Rineka Cipta.

Sutrisno, E. 2009. Manajemen Sumber Daya Manusia. Jakarta : Kencana Prenada Media Group.

Umar Husein, 2002. Metode Riset Bisnis. Jakarta : Gramedia Pustaka Utama

Winarni. 2005. Pengaruh Umur, Masa Kerja, Dan Upah Bonus terhadap produktivitas Tenaga Kerja Bagian Cerutu Pada Koperasi Karyawan Kartanegara PTPN (Persero) Desa Candijati Kecamatan Arjasa Kabupaten Jember. Jember : Universitas Jember.

Wirosuharjo. 1996. Pengembangan Sumber Daya Manusia. Kesempatan Kerja dan Pengembangan Ekonomi. Jakarta : Rineka Cipta.

Wulan, 2011. Faktor - Faktor Yang Mempengaruhi Produktivitas Tenaga Kerja Afdeling Di PTPN XII (Persero) Kebun Kotta Blater Jember - Jawa Timur. Jember : Politeknik Negeri Jember. 